JOURNAL

of Health Inequalities

\title{
Smoking- or nicotine-free generation, or both? What should be the public health priority?
}

\author{
Witold A. Zatoński ${ }^{1,2}$, Leif E. Aaro ${ }^{3}$, Oddun Samdal ${ }^{4}$, Joanna Mazur ${ }^{5}$ \\ ${ }^{1}$ Health Promotion Foundation, Nadarzyn, Poland \\ ${ }^{2}$ Higher Vocational State School in Kalisz, Poland \\ ${ }^{3}$ Norwegian Institute of Public Health, Bergen, Norway \\ ${ }^{4}$ University of Bergen, Bergen, Norway \\ ${ }^{5}$ Institute of Mother and Child, Warsaw, Poland
}

\begin{abstract}
In many highly developed countries the prevalence of tobacco smoking is declining. This trend seems to be particularly marked among adolescents. Even in countries with a relatively short history of tobacco control programmes, such as Poland, this decline is strong. In Norway, the prevalence of daily smokers among 15-year-old adolescents, both genders combined, is under $2 \%$. Marketing of e-cigarettes may represent a challenge for sustaining these positive trends. The strongest argument in favor of allowing the sales and marketing of e-cigarettes is their use as a cessation tool for established smokers. However, a disagreement persists within the scientific community regarding the effectiveness of e-cigarettes as an aid for quitting smoking. There is also a strong concern whether young people could be recruited into nicotine dependence using non-tobacco nicotine delivery products, and eventually, into the use of traditional combustible cigarettes. Experiences from Poland and Norway indicate that effective tobacco control can lead to significant decreases in smoking prevalence among children and adolescents. Aggressive marketing of e-cigarettes must not be allowed to interfere with this development.
\end{abstract}

KEY WORDS: tobacco, e-cigarettes, adolescents, Poland, Norway.

ADDRESS FOR CORRESPONDENCE: Witold A. Zatoński, Health Promotion Foundation, 51 Mszczonowska Street, 05-830 Nadarzyn, Poland, e-mail: wazatonski@promocjazdrowia.pl

On the tobacco control front, the situation has been gradually improving in the last decades in Europe, including the countries of its eastern half. In Poland, the sale of cigarettes has been showing a steady decline since the 1990s, from 100 billion cigarettes a year in 1990 to 40 billion in 2014 [1]. In several countries of Western Europe, the improvement has been even more marked. An example of this trend is Great Britain, where the smoking prevalence among adults (16 years and older) in 2015 has fallen to $16.9 \%$, the lowest level recorded since 1974 when national surveys on smoking in Great Britain first began [2].

However, during the last decade, the largest changes in smoking rates in Europe and the United States were observed among children [3, 4]. Smoking among children is a particularly important indicator because the clear majority of smokers pick up the habit in their adolescence or during their teenage years. Initiation of smoking after the age of 25 is rare [5]. Due to this fact, every evidence-based tobacco control programme, with the goal of achieving long-term results, should emphasize the prevention of smoking initiation among children and youth [6].

One of the best measures of smoking among adolescents is the rate of daily smoking. In Poland, in the years 2004-2014, the proportion of daily smokers in all age groups decreased by half. In 2014, the proportion of daily smokers among 15-year-old children was around $10 \%$ in both genders. In the group of 13-year-old youth, it was $4.2 \%$ in boys and $5.3 \%$ in girls. Finally, in the group of 11 -year-old children, it was around $1.5 \%$ in both genders (Fig. 1) [7, 8]. 
During the last years, some signs of a slowdown of the smoking prevalence decline among girls in Poland have been observed (11-, 13-, and 15-year-olds). Among boys, this slowdown seems not to have taken place (Fig. 1). There have been suggestions that this could be an effect of the appearance on the Polish market of e-cigarette products, their aggressive marketing, and their growing popularity among children [9-12]. However, it is still too early to conclude whether this is the case.

However, the real revolution in smoking among children in the last decade took place in Norway. In 2001, Dagfinn Høybråten, then the Health Minister of Norway, announced that his goal was to reduce smoking among children in grades 8-10 (age 13-15) by half. A few years later, this goal was reached. Now, fifteen years later, studies show that the decline has continued. The proportion of daily smokers among children aged 15 in Norway in 2014 was down to $2.1 \%$ among boys and $0.6 \%$ among girls [3]. This example of the success in the fight against smoking among children in Norway is another piece of evidence indicating that a complete eradication of smoking is within a reach.

In 2014 , daily use of snus among 15-year-old was reported by $9.5 \%$ of the boys and $3.9 \%$ of the girls, slightly (insignificantly) lower than in 2010 [13]. During 2002-2010, among 16-17-year old's, smoking of cigarettes decreased, and use of snus increased [14]. To what extent use of snus has replaced use of cigarettes and thereby contributed to the decline of smok-

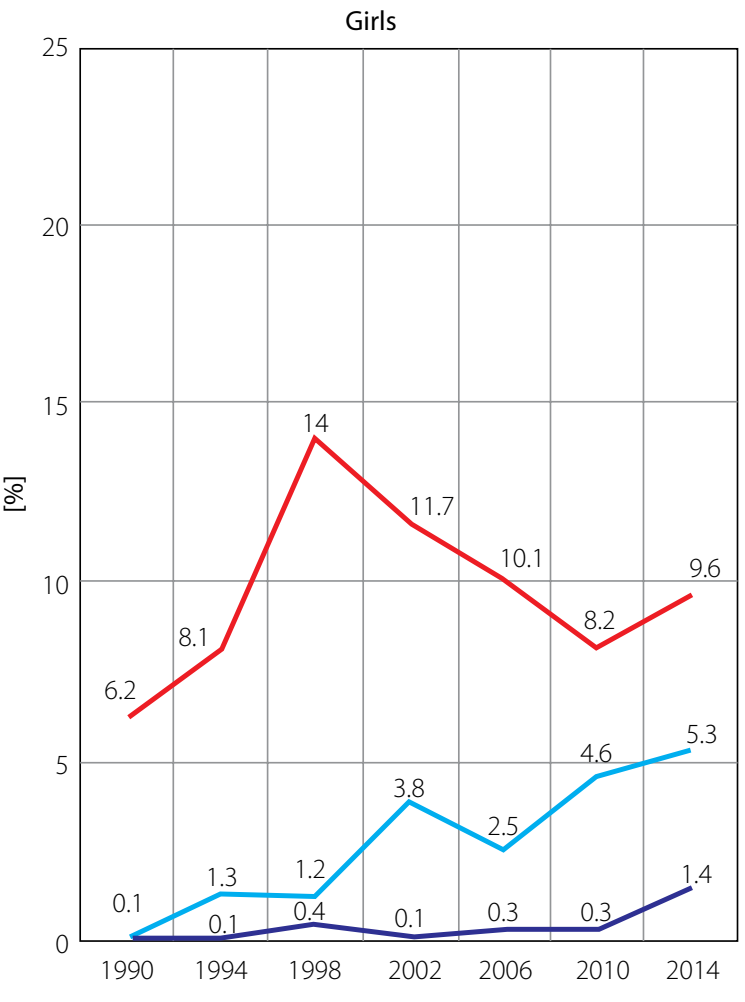

ing prevalence among adolescents in Norway needs further study.

The struggle against the use of traditional cigarettes must remain the focus of public health efforts in the years to come. The belief that e-cigarettes are the silver bullet that will lead to the eradication of tobacco-related diseases may turn out to be an illusion not sufficiently supported by scientific evidence. Some studies suggest that their effect might be the opposite, as the development of the e-cigarette market could disrupt the steady progress that tobacco control has made towards a smokefree generation [15]. Some research has indicated that use of e-cigarettes among youth may increase the risk of starting using conventional cigarettes [16]. The increasing popularity of a device that vaporises pure nicotine should not be treated as a replacement for concerted efforts towards building health competence in any society. While e-cigarettes, if proven to be more or less harmless, could have their place as one of the many forms of tobacco cessation aids, and they should be subject to all the legal rigors and regulations that are required of this type of drugs. This belief is reflected in the new legislation passed in July 2016 by the Polish government [17], which, among others prohibits the sale of e-cigarettes to children under 18 years of age, the advertising of e-cigarettes, as well as the use of e-cigarettes in public places (just as is the case with traditional cigarettes).

In Norway, production, import, and sales of e-cigarettes and e-juice containing nicotine have been pro-

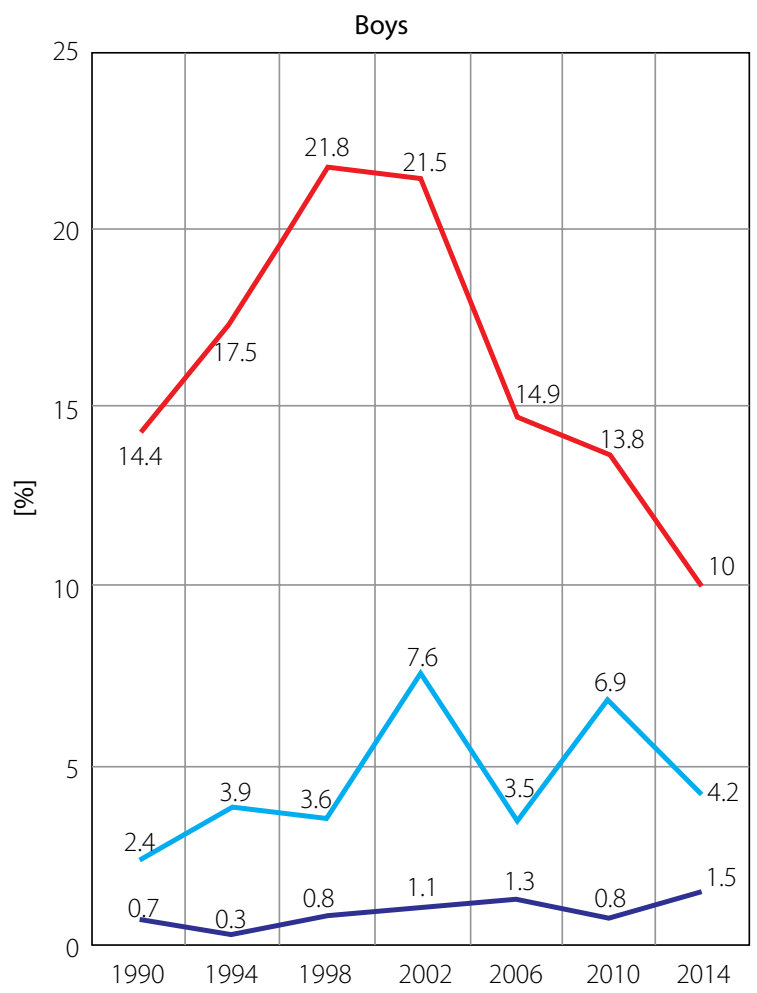

FIG. 1. Time trend of smoking (at least one cigarette a day) in girls and boys aged 11-15 years in Poland in the years 1990-2014 
hibited but some private import and use of e-cigarettes is taken place. With the connection to the recent EU Tobacco Products Directive [18], the Norwegian tobacco legislation has been revised, and the legislation has been expanded to cover e-cigarettes as well. Import and sales of e-cigarettes containing nicotine will be legal from 2017. This is to make e-cigarettes easily available for established smokers who would like to stop smoking, and to increase product control. The tobacco legislation has been adjusted to include regulations on e-cigarettes. Some regulation of product and sales, largely consistent with regulations related to tobacco products, as well as the EU Tobacco Products Directive are in place. Regulations include:

- registration at least six months in advance with The Norwegian Medicines Agency of all kinds of e-cigarettes to be sold on the Norwegian market,

- health warnings on packets,

- prohibition of self-service in places where the product is sold,

- ban on use of e-cigarettes in public places,

- ban on advertising (with minor exceptions related to internet-based display of products),

- prohibition of sales to customers under 18 years of age. Separate regulations will be issued on exceptions from the ban on prohibition of product display in establishments where e-cigarettes are sold.

In summary, the rates of smoking have been steadily decreasing in the last decades, not only in Norway or the USA, but also in less wealthy countries such as Poland. The question of tobacco control today is whether smoking of traditional cigarettes will be replaced using pure nicotine administered by various types of nicotine delivery devices, such as e-cigarettes, or the more recent Next Generation Nicotine Delivery products, which are becoming available on global markets [19]. In the report of the US Surgeon General published in December 2016, it was indicated that in the USA, in 2014 more children used nicotine delivery devices (so-called electronic cigarettes) than smoked conventional cigarettes. In the report from the U.S. Surgeon General, several harmful effects of use of e-cigarettes are mentioned. The full impact of e-cigarette use on health is not yet known [20, 21]. An additional concern is whether the first contact with addictive substances for children will be increasing in the form of marijuana and other psychoactive substances, which are being legalised in growing number of countries and regions. We do not yet know what the scale of this occurrence will be, but it is important for the tobacco control community to continue to monitor these developments closely, before they are faced with a new serious public health problem and a growing risk to physical and mental health of children.

\section{DISCLOSURE}

Authors report no conflict of interest.

\section{References}

1. Zatoński M, Zatoński WA, Przewoźniak K, Jaworski M. The significance and impact of the Polish Anti-Tobacco Law. J Health Inequal 2016; 2: 32-35.

2. Cancer Research UK. Smoking rate hits low in England. Available from: http://www.cancerresearchuk.org/about-us/cancernews/news-report/2016-08-02-smoking-rate-hits-low-in-england (accessed 2 November 2016).

3. Aarø, LE, Mazur J, Zatoński WA, Samdal O. Trends in smoking among Polish and Norwegian youth 1986-2014. J Health Inequal 2016; 2: 44-51.

4. Johnston LD, O’Malley PM, Miech RA, et al. Monitoring the Future national survey results on drug use, 1975-2015: Overview, key findings on adolescent drug use. Ann Arbor MI 2016, Institute for Social Research. The University of Michigan. Available from: http://www.monitoringthefuture.org/pubs/monographs/ mtf-overview2015.pdf (accessed 3 June 2016).

5. U.S. Department of Health and Human Services. Preventing Tobacco Use Among Youth and Young Adults: A Report of the Surgeon General. Atlanta (GA): U.S. Department of Health and Human Services, Centers for Disease Control and Prevention, National Center for Chronic Disease Prevention and Health Promotion, Office on Smoking and Health, 2012.

6. Schüz J, Espina C, Villain P, et al. Working Groups of Scientific Experts. European Code against Cancer $4^{\text {th }}$ Edition: 12 ways to reduce your cancer risk. Cancer Epidemiol 2015; 39 (Suppl 1): S1-S10.

7. Kowalewska A. Tobacco smoking. In: Mazur J (ed.). Health and health behaviors of school children in Poland and selected socio-economic determinants. Results from HBSC 2014. Institute of Mother and Child, Warsaw 2015.

8. Mazur J, Dzielska A, Kowalewska A, Fijałkowska A. Current trends in tobacco smoking among 15-year-old adolescents in Poland in the background of 30 countries. Prz Lek 2016; 73: 685-689.

9. Goniewicz M, Gawron M, Nadolska J, et al. Rise in Electronic Cigarette Use Among Adolescents in Poland. J Adolescent Health 2014; 55: 713-715.

10. Primack BA, Soneji S, Stoolmiller M, et al. Progression to traditional cigarette smoking after electronic cigarette use among US adolescents and young adults. JAMA Pediatr 2015; 169: 1018-1023.

11. Leventhal AM, Strong DR, Kirkpatrick MG, et al. Association of electronic cigarette use with initiation of combustible tobacco products smoking in early adolescence. JAMA 2015; 314: 700-707.

12. Wills TA, Knight R, Sargent JD, et al. Longitudinal study of e-cigarette use and onset of cigarette smoking among high school students in Hawaii. Tob Control 2016; doi: 10.1136/ tobaccocontrol-2015-052705.

13. Samdal O, Mathisen FKS, Torsheim T, et al. Helse og trivsel blant barn og unge. Resultater fra den landsrepresentative spørreundersøkelsen «Helsevaner blant skoleelever. En WHO-undersøkelse i flere land». HEMIL-Report 1/2016. Bergen: Department of Health Promotion and Deveopment, 2016.

14. Pedersen $\mathrm{W}$, von Soest $\mathrm{T}$. Tobacco use among Norwegian adolescents: from cigarettes to snus. Addiction 2014; 109: 1154-1162. 
15. Dutra LM, Glantz SA. E-cigarettes and conventional cigarette use among US adolescents: A cross-sectional study. JAMA Pediatr 2014; 168: 610-617.

16. Primack BA, Soneji S, Stoolmiller M, et al. Progression to traditional cigarette smoking after electronic cigarette use among U.S. adolescents and young adults. JAMA Pediatr 2015; 169: 1018-1023.

17. Dz.U.2016 poz. 1331. Ustawa z dnia 22 lipca 2016 r. o zmianie ustawy o ochronie zdrowia przed następstwami używania tytoniu i wyrobów tytoniowych [Journal of Laws of the Republic of Poland, 2016, pos. 1331. Law from 22 July 2016 regarding changes of the law on protection of health from the consequences of using tobacco and tobacco products].

18. Directive 2014/40/EU of the European Parliament and of the council of 3 April 2014. Official Journal of the European Union, L127/1. Available from: http://ec.europa.eu/health/sites/health/files/tobacco/docs/dir_201440_en.pdf (accessed 2 November 2016).

19. Six Telling Stats on the iQOS Electronic Cigarette. What retailers and customers are saying about Philip Morris' heat-notburn product. Available from: http://www.cspdailynews.com/ category-news/tobacco/articles/6-telling-stats-iqos-electronic-cigarette (accessed 2 November 2016).

20. US Department of Health and Human Services. E-cigarette use among youth and young adults. A report of the Surgeon General. US Department of Health and Human Services, Centers for Disease Control and Prevention, National Center for Chronic Disease Prevention and Health Promotion, Office on Smoking and Health, Atlanta, 2016.

21. Murthy VH. E-cigarette use among youth and young adults. A major public health concern. JAMA Pediatr 2016. Dec 8 doi: 10.1001/jamapediatrics.2016.4662. Available from: http:// jamanetwork.com/journals/jamapediatrics/fullarticle/2592300 (accessed: 12 December 2016).

\section{AUTHORS' CONTRIBUTIONS}

WAZ prepared concept and design of the publication. WAZ and LEA collected data and analysed them, critically revised and finally approved the article. WAZ, LEA, OS and JM participated in writing the article. 